\title{
PERKEMBANGAN MORAL SISWA KELAS VI MADRASAH IBTIDAIYAH MA'ARIF SOKORINI KEC. MUNTILAN KAB. MAGELANG MENURUT TEORI LAWRENCE KOHLBERG
}

\author{
Oleh : \\ Paiman \\ Universitas Cokroaminoto Yogyakarta
}

\begin{abstract}
Abstrak
Penelitian ini bermaksud untuk mengetahui perkembangan moral siswa kelas VI MI Ma'arif Sokorini Magelang menurul Lawrence Kohlberg. Dengan demikian permasalahan yang akan dipecahkan adalah pada tahap apakah perkembangan moral siswa kelas VI MI Ma'arif Sokorini yang sesuai dengan tahapan pada teori Lawrence Kohlberg. Penelitian ini merupakan penelitian deskrptif kualitatif,pengumpulan data melalui kuesioner, subjek penelitian ini yaitu siswa kelas VI, analisis data dengan analisis kualitatif melalui tahap-tahap reduksi data, display, conclusions drawing and veifying, triangulasi dan kesimpulan.

Hasil analisis data penelitian menunjukkan perkembangan moral siswa kelas VI MI Ma' arif Sokorini berada pada thapan pra konvensional dimana pada tahap ini siswa memiliki ketaatan terhadap hokuman dan kepatuhan, anak taat pada peraturan. Patuh terhadap peraturan untuk menghindari hukuman. Disamping itu pada tahap ini siswa melakukan tindakan perbuatan baik bukan karena masalah keikhlasan tetapi lebih karena mengharap suatu balasan atau hadiah.
\end{abstract}

Kata kunci : moral siswa, dan teori Lawrence Kohlberg.

\section{A. Pendahuluan}

Pendidikan anak usia sekolah dasar merupakan salah satu bentuk penyelenggaraan pendidikan yang menitik beratkan pada pertumbuhan dan perkembangan moral, yaitu pertumbuhan dan perkembangan moral dengan mengkoordinasikan antara motorik halus dan kasar. Perkembangan moral pada anak perlu mendapatkan perhatian khusus, sebab berkaitan dengan pembentukan karakter siswa sejak masih disekolah dasar sampai mereka dewasa.

Pada siswa kelas VI Sekolah Dasar, yang sebagian besar berumur sekitar 12-13 tahun, memiliki perkembangan social dan oral yang berbeda dengan siswa kelas I, II, III. Pada usia tersebut, anak sudah mulai melakukan tindakan bukan karena takut hukuman, namun lebih 
kepada tujuan yang ingin dicapainya atau keuntungan untuk dirinya. Namun pada usia siswa kelas VI justru lebih mudah terpengaruh oleh hal-hal negative. Sebab pada usia tersebut, anak mulai mencoba-coba sesuatu. Keingin tahuan akan sesuatu hal sangat besar, terkadang kurang mempertimbangkan baik dan buruk akibat dari tindakannya. Itulah sebabnya pentingnya memberikan pendidikan moral kepada anak-anak disekolah dasar terutama kelas VI. Ini dilakukan sebagai upaya untuk meningkatkan kematangan moral dan pembentukan karakter siswa, sehingga siswa memiliki pribadi yang berpengetahuan moral, peranan perasaan moral dan tindakan atau perilaku moral. Pelaksanaan pembelajaran dengan menekankan pengetahuan tentang nilai-nilai moral, siswa mempunyai pegangan dalam melakukan tindakan. Dengan pegangan nilai-nilai moral tersebut, siswa dapat berpikir tindakan mana yang boleh dilakukan dan yang tidak boleh dilakukan. Sehingga tindakan-tindakan negative yang mengarah pada dekadensi moral dapat terhindari. Namun pada kenyataannya pelaksanaan pembelajaran lebih banyak menekankan pada ranah kognitif saja, dengan penekanan pada penguasaan materi saja, akan tetapi mengabaikan pendidikan nilai dan moral. Akibatnya siswa terbentuk menjadi generasi yang egois, matrealistis, berbudi pekerti yang rendah dan memberontak.

Perkembangan moral adalah ukuran dari tinggi rendahnya moral seseorang berdasarkan perkembangan penalaran moralnya seperti yang diungkapkan Lawrence Kohlberg, yaitu penalaran moral yang diakibatkan oleh suatu tindakan atau tingkah laku. Tingkah laku baik secara moral, selalu merupakan tingkah laku yang rasional, suatu tingkah laku yang sengaja dilakukan secara mau dan tahu.

Berdasarkan latar belakang masalah diatas, penulis mengajukan judul penelitian tentang Perkembangan Moral Siswa Kelas VI Sekolah Dasar menurut Teori Lawrence Kohlberg di Madrasah Ibtidaiyah Ma’arif Sokorini Kecamatan Muntilan Kabupaten Magelang.

\section{B. Pembahasan}

Pendekatan terhadap masalah pertimbangan moral Kohlberg memusatkan perhatiannya pada bentuk kualitatif dari penalaran moral anak-anak dan perubahan-perubahan yang berkaitan dengan perkembangan dari penalaran tersebut. Kohlberg telah berupaya untuk memberikan deskripsi umum mengenai cirri-ciri pokok structural dan keorganisasian dari pertimbangan moral yang dapat diamati perkembangannya dalam tahap-tahap yang teratur (William M.K, 1992:66). Dilihat oleh Kohlberg bahwa setiap orang melewati tahap-tahap dengan urutan yang sama, 
meskipun ada perkembangan tidak sama dan belum tentu mencapai thap yang tertinggi. Adapun tahap-tahap perkembangan moral itu pada garis besarnya adalah sebagai berikut:

1. Level pra konvensional:

a. Tahap : punishment and obedient orientation atau hukuman dan ketaatan

b. Tahap : relativis instrumental orientation atau hubungan antar manusia dianggap alat seakan hubungan tersebut seperti penjual dan pembeli.

2. Level konvensional :

a. Tahap : interpersonal concordance atau good boy and nice girl orientation atau persamaan dengan orang lain atau mengidentifikasikan dirinya dengan orang lain.

b. Tahap : law and order orientation atau taat pada hokum

3. Level pos konvensional :

a. Tahap : social contract legalistic orientation atau keputusan social.

b. Tahap : universal ethical principles orientation atau memegang prinsip etika.

\section{C.Hasil Penelitian}

Responden dalam peneltian ini adalah siswa kelas VI MI Ma'arif Sokorini Magelang, berjumlah 20 orang. Dengan rincian jumlah siswa perempuan 7 orang dan laki-laki 13 orang. Dalam penelitian ini menggunakan kuisioner untuk mengetahui tahapan-tahapan perkembangan moral yang sesuai dengan perkembangan siswa kelas VI. Dengan mencentang pilihan yang dipilihnya. Berikut pedoman kuisioner yang dibagikan kepada siswa beserta table hasil isian :

\begin{tabular}{|c|c|c|c|c|}
\hline No & Tindakan siswa & Hukuman \& Hadiah & Kewajiban & Hak \& nilai moral \\
\hline 1. & $\begin{array}{l}\text { Alasan mentaati peraturan } \\
\text { sekolah }\end{array}$ & & & \\
\hline 2. & $\begin{array}{lll}\text { Alasan mengapa } & \text { harus } \\
\text { menghormati teman } & \text { yang } \\
\text { sedang sholat } & & \\
\end{array}$ & & & \\
\hline 3. & $\begin{array}{l}\text { Alasan melaksanakan } \\
\text { hukuman karena melakukan } \\
\text { pelanggaran }\end{array}$ & & & \\
\hline 4. & $\begin{array}{l}\text { Alasan menghormati guru, } \\
\text { teman dan masyarakat }\end{array}$ & & & \\
\hline 5. & $\begin{array}{l}\text { Alasan dating tepat waktu } \\
\text { kesekolah }\end{array}$ & & & \\
\hline
\end{tabular}




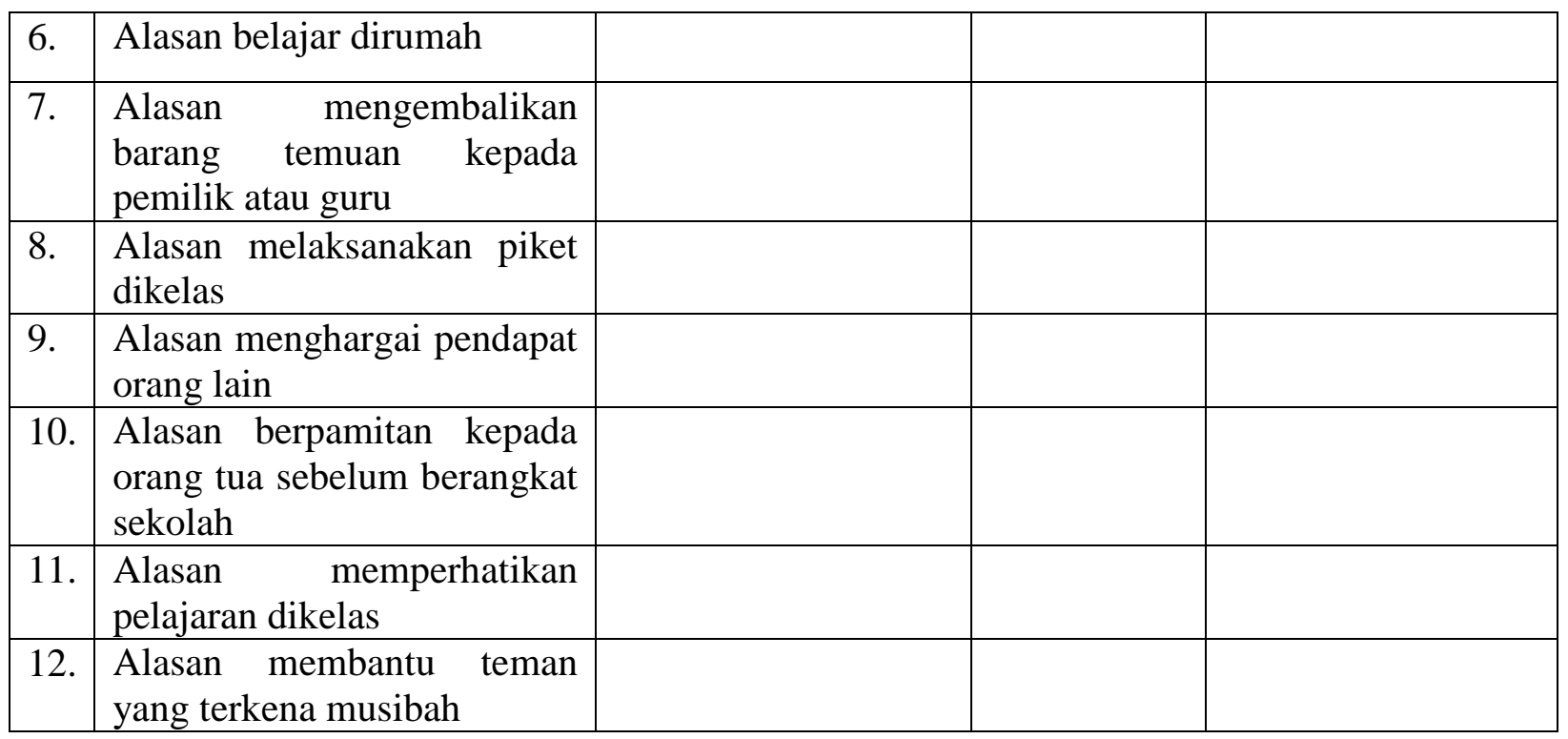

Keterangan : table diatas adalah table pedoman kuisioner dengan rincian kolom sebagai berikut :

1. Pada kolom hukuman dan hadiah adalah indicator yang digunakan untuk menunjukkan tindakan siswa yang disesuaikan dengan perkembangan moral pada tahap pra konvensional (tahap 1).

2. Pada kolom kewajiban untuk menunjukkan tahapan perkembangan moral konvensional (tahap 2).

3. Pada kolom hak dan nilai-nilai moral digunakan sebagai indicator perkembangan moral pada tahap post-konvensional (tahap 3)

Table hasil penelitian dengan kuisioner kelas VI MI Ma'arif Sukorini

\begin{tabular}{|l|l|l|l|l|}
\hline No & \multicolumn{1}{|c|}{ Nama } & Tahap 1 & Tahap 2 & Tahap 3 \\
\hline 1 & Andika & V & V & V \\
\hline 2 & Nabil Uzul Islam & V & & \\
\hline 3 & Ngabdurohman & V & & \\
\hline 4 & Hanna Tri Afifah & V & & \\
\hline 5 & Hidayati & V & & \\
\hline 6 & Ahmad Yusuf & V & V & \\
\hline 7 & Arif Ahmad Rifai & V & V & \\
\hline 8 & M. Maksum & V & & V \\
\hline 9 & Galang Arjun Putra & V & V & \\
\hline 10 & Sunarno & V & V & \\
\hline 11 & Fayid & V & V & \\
\hline 12 & Ulfah Aulia Dewi & V & & \\
\hline
\end{tabular}




\begin{tabular}{|l|l|l|l|l|}
\hline 13 & Anjas Setyoko & V & V & V \\
\hline 14 & Siti Khoirul & V & & \\
\hline 15 & Aldi Setyawan & V & & \\
\hline 16 & Nur Prasetyo & V & & V \\
\hline 17 & Novia Sari & V & & \\
\hline 18 & Sujatmiko & V & V & \\
\hline 19 & Rahmatin & V & V & \\
\hline
\end{tabular}

Berdasarkan hasil pengisian kuisioner oleh siswa kelas VI Madrasah Ibtidaiyah Ma'arif Sokorini dapat diketahui siswa kelas VI sebagian besar menepati tahapan perkembangan moral pada tahap pra konvensional. Data ditunjukkan melalui hasil angket setelah dianalisis, menunjukkan siswa lebih banyak melakukan tindakan didasarkan atas ketaatan terhadap hukuman serta pemberian balasan dari orang lain. Sedangkan pada tahap konvensional , sebanyak 9 siswa memilih jawaban dengan indicator yang menunjukkan perkembangan moral siswa pada tersebut. Kemudian tahap post konvensional siswa yang memilih indicator tahapan tersebut sebanyak 4 siswa. Berdasarkan data tersebut penulis mengambil kesimpulan bahwa perkembangan moral siswa kelas VI MI Ma'arif Sokorini berada pada tahapan pra konvensional, dimana pada tahap ini siswa memiliki ketaatan terhadap hukuman dan kepatuhan, anak taat pada peraturan. Patuh pada peraturan untuk menghindari hukuman. Disamping itu pada tahap ini siswa melakukan tindakan perbuatan baik bukan karena masalah keikhlasan tetapi lebih karena mengharap suatu balasan atau hadiah.

Berdasarkan pengamatan kelas, ditunjukkan sikap siswa dalam mengikutib pelajaran, keaktifan siswa dalam mengemukakan pendapat serta aktifitas siswa dalam mengikuti kegiatan ekstrakulikuler disekolah. Sikap siswa terhadap pelaksanaan pembelajaran dikelas, siswa memperhatikan, mendengarkan penjelasan guru dikelas. Siswa juga bersikap tenang, dan menempati tempat duduk sesuai dengan yang telah ditentukan. Selain itu dalam mengikuti kegiatan ekstra kulikuler sebagian besar siswa aktif dalam mengikuti kegiatan tersebut. Perkembangan moral siswa ketika mengikuti kegiatan belajar mengajar, meliputi keaktifan siswa mengikuti KBM, sikap dan tingkah laku siswa dikelas serta aktivitas siswa mengikuti kegiatan ekstrakulikuler disekolah. 


\section{Kesimpulan dan Saran}

Berdasarkan hasil penelitian dan pembehasan mengenai perkembangan moral siswa kelas VI MI Sokorini berorientasi pada teori Kohlberg, penulis dapat menyimpulkan hasil pembahasan sebagai berikut :

1. Perkembangan moral siswa kelas VI MI Ma'arif Sokorini berada pada tahapan pra konvensional, dimana pada tahap ini siswa memiliki ketaatan terhadap hukuman dan kepatuhan, anak taat pada peraturan. Patuh terhadap peraturan untuk menghindari hukuman. Disamping itu pada tahap ini siswa melakukan tindakan perbuatan baik bukan karena masalah keikhlasan tetapi lebih karena mengharap suatu balasan atau hadiah.

2. Sikap siswa terhadap pelaksanaan pembelajaran dikelas, siswa memperhatikan, mendengarkan penjelasan guru dikelas. Siswa juga bersikap tenang dan menempati tempat duduk sesuai dengan yang telah ditentukan. Selain itu dalam mengikuti kegiatan ekstrakulikuler sebagian besar aktif dalam mengikuti kegiatan tersebut.

Adapun saran peneliti antara lain:

1. Perlunya koordinasi antara guru, orang tua dan masyarakat dalam mengontrol setiap perkembangan setiap perkembangan moral siswa khususnya perkembangan moral siswa sekolah dasar.

2. Perlunya guru memahami kondisi siswa serta latar belakang siswa secara detail, agar guru dapar memonitor setiap perkembangan moral siswa. Sehingga dapat menghindari sikap dan sifat yang negative akibat pengaruh dari luar yang dapat membawa dampak buruk.

3. Perlunya dilakukan secara intensif pembinaan moral di sekolah.

\section{Daftar Pustaka}

Abu ahmadi dan Chalid Narbuka, (1999) Metode Penelitian. Jakarta : Bumi Aksara

Ronald Duska dan Mariellen Whelan, (1982) Perkembangan Moral Perkenalan dengan Piaget dan Kohlbeg (Terjemahan Dwija Atmaja). Yogyakarta : Yayasan Kanisius.

Soenarjati, Dra. Drs. Cholisin (2002) Dasar-dasar Pendidikan Moral dalam Kurikulum Sekolah, cetakan ke V. Yogyakarta: Goeboek Indonesia

Tata Usaha, Biografi dan Data Administrasi Sekolah, (2011) MI Ma'arif Sokorini Magelang 